\title{
Verbal Repetition in Neuro-Linguistic Programming with Special Reference to the Political Speeches of Egyptian and American Leaders $^{(*)}$
}

\author{
Dr. Reham Khalifa \\ University of Damietta, Faculty of Arts
}

\section{الملخص}

التكرار اللفظي في البرمجة اللغوية العصبية مع إثارة خاصة إلى

الخطابات السياسية للقادة المصريين والأمريكيين

نجاح السياسي بعتمد على قدرته في التأثير على الآخرين وتغير ما بعتقدون

و الاقتناع بما ير اه القائد مناسبا. لذا يسعي السياسيون الي استخدام الوسائل التي تمكنهم من التحكم في عقول العامة وأحد هذه الوسائل هي البرمجة اللغوية العصبية التي تعتمد على بلى

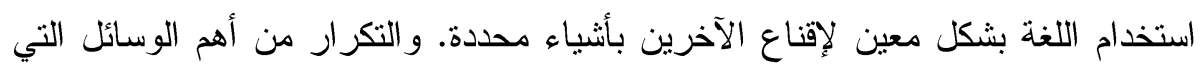
تدعم البرمجة اللغوية العصبية والبحث الحالي يهدف الي دراسة التكرار اللفظي لمعرفة أي شكل من أنتكاله التي تزيد فاعلية البرامج اللغوية العصبية المستخدمة في التأثير على لثى الآخرين في المجال السياسي ولتحقيق هذا الهدف تم تحليل محتوي أربعة خطابات لكل من الرئيس الأمريكي جورج بوش والرئيس الأمريكي بار الك أوباما والرئيس المصري

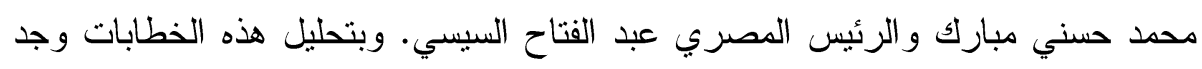
انهم يستخدمون مختلف أنو اع التكرار اللفظي بنسب مختلفة ولكن القادة المصريين أكثر استخداما للتكرار اللفظي بصفة عامة. و اتفق القادة الأربعة على استخدام تكرار المفردات أكثر من أي شكل آخر من أشكال التكرار اللفظي ويعد التكرار الصوتي أقل أثكال التكرار اللفظي استخداما لدي القادة الأربعة.

${ }^{(*)}$ Bulletin of the Faculty of Arts Volume 79 Issue 4 April 2019 


\begin{abstract}
Political leadership is one of the fields that depend on influencing others to get their support and trust and to frame their minds. NeuroLinguistic Programming is emerging as a set of techniques that make use of the power of words in influencing others. The objective of this study was to explore the forms of verbal repetition that were used to enhance the effects of Neuro-Linguistic Programming in the field of political leadership. Four influential speeches of four political leaders, Mohamed H. Mubarak, Abdel Fattah Al-Sisi, George W. Bush and Barack Obama, were chosen for the purpose of this study. Textual analysis was conducted to analyze the content of the four speeches quantitatively and qualitatively. The results indicated that the four political leaders used neuro-linguistic programming techniques to influence the public. In order to strengthen the effects of the employed neuro-linguistic programming techniques, the four leaders utilized different forms of verbal repetition. Lexical repetition was found to be the most common form of repetition in the political speeches of the four leaders. By comparing the use of repetition in the speeches of the Egyptian leaders, Mubarak and Al-Sisi, and the American leaders, Bush and Obama, it was found that the Egyptian leaders tended to use different forms of repetition more than the American leaders.
\end{abstract}

Keywords: neuro-linguistic programming, repetition, political leadership

\title{
Introduction
}

Language is a human feature. People put words together to fit a specific situation and to communicate their thoughts, feelings and desires (Qiu, 2014). A word is not innocent as it stands in a dictionary (Blaney, 2014) because words have the potentiality to construct worlds (Johnson, 2012, p.4). Words have a magic effect as they change the neurochemistry properties in the brains of people who receive these words (Newberg \& Waldman, 2013, pp.23-38). The words people use to convey their thoughts open their inner world of meaning to their audiences' worlds. So, words have the power of shaping thoughts, changing minds and influencing behavior (Bowman, Ronch, \& Madjaroff, 2010). 
The influence of words on mind and behavior became the interest of the studies of Neuro-Linguistic Programming (NLP). These studies focus on analyzing systematically human communication which is considered a means for framing minds (O'Connor, 2001, p.1). NLP is a practical skill that responsible people use to change the world according to their will by imposing values on others around them (O'Connor \& Seymour, 1993, p.2). Politics is the art by which politicians influence the public and direct them to willingly do what the politicians think to be right (Triadafilopoulos, 1999). Since one of the most important outcomes of NLP is to influence and direct others, politicians wield the power of NLP to persuade the public with their values. They use words in a specific way to direct people's minds and to shape the public opinion (O'Connor, 2001, p. 54).

Repetition is one of the anchors on which NLP is based (O'Connor, 2001, p. 54). Repetition is essential for moving things to the long term memory (Vaknin, 2011, p. 341). The power of words that are repeated many times is strengthened due to its resonation and echo in the mind of people (Johnson, 2012, pp.1-8).

\section{Problem of the study}

Political leaders as all leaders try to win the minds and hearts of the public (Brower, Fiol, \& Emrich, 2007). They use different functional communication techniques to achieve this purpose. NLP techniques are of the modern techniques that attract the attention of leaders everywhere (Zulkifli, 2015). As there is an increasing interest in employing NLP, some of the research focused on evaluating the effects of NLP in different fields such as sale, learning and politics such as Brower, Fiol, and Emrich, 2007; Bashir and Ghani, 2012; and Oberholzer, 2013. Some other research focused on the effective NLP techniques such as Zulkifli, 2015 and Wilimzig and Nielsen, 2017. Little research has manipulated the linguistic features that the political leaders could use to strengthen the effects of NLP techniques such as Vaknin (2008, p.80) and Oberholzer (2013) who referred to the 
importance of repetition in intensifying the effects of NLP techniques. However, research that indicates the forms of repetition that may enhance the use of NLP was not detected. So, more research is required in the linguistic field to explore the forms of repetition that support NLP techniques.

\section{Theoretical background}

The theoretical background is divided into two main sections. The first section manipulates NLP and its techniques. The second section focuses on the use of different forms of verbal repetition.

\section{A. Neuro-Linguistic Programming}

NLP is a modern field of study that seeks to realize brilliance and quality in interpersonal communication (O'Connor, 2001, p. V). In other words, NLP is the art and science of using effective language to achieve superiority in the areas of communication, influencing others, managing change and setting and achieving goals (Tosey, \& Mathison, 2009, p.15). Excellent interpersonal communications help organize people's states of minds including thinking, emotions, attention and concentration. So, NLP focuses on analyzing patterns of people's behavior and communication (Hejase, Tartozi \& Hashem, 2015).

NLP is a multifaceted field that is derived from three areas of study. The first is "neurology" which focuses on how the information obtained by the human senses could be processed by the nervous system. Second, the area of "linguistics" that concentrates on the use of language and its effects on people. The third area is "programming" which refers to the process of sequencing and repeating the components of a system to achieve specific goals (Wełyczko, 2016). Thus, NLP is a practical skill that attracts the attention of practitioners in different fields such as psychotherapy, education and learning, business and marketing, advertising and politics and leadership (Bashir \& Ghani, 2012). As NLP is utilized in different fields, there is no overt comprehensive definition for it (Wełyczko, 2016). NLP 
practitioners tend to define it operationally as the techniques that contact with the recipients' subconscious mind resulting in communicating and persuading people effectively. So, NLP is based on a set of techniques which are adopted to change minds and achieve what is considered impossible. Some of the commonly used NLP techniques are illustrated in the following section.

\section{Reframing}

Reframing is an NLP technique that depends on the reinterpretation of events by posing a different viewpoint. Words are used to reframe meaning or content and to change the realization of anything (Wilimzig \& Nielsen, 2017), e.g., realizing war as related to death and destruction can be reframed to make war be realized as a way to get freedom and liberty or to secure the future of the new generation. So, reframing enables leaders and politicians to place the content of a situation in a new frame. Reframing helps leaders handle objections, change the perspective of an issue, make people respond differently, and retrieve the confidence of the public (Zulkifli, 2015).

\section{Anchoring}

Anchoring is an NLP technique that depends on the power of the emotional states in influencing one's thinking and behavior. It associates a specific internal response with an external or internal anchor (Oberholzer, 2013). The idea of anchoring goes back to Milton Erickson's hypnosis model. Throughout this model, Erickson used cues as anchors to make people alter their internal states (Ready \& Burton, 2010, pp-148-149). This anchor could be visual, auditory or kinesthetic stimulus (Martlew, 2004, p.131). Anchoring makes people think in specific ideas or to reject unrequired ideas. Anchors are weak in the beginning because people's minds are still aware of these anchors. With practice and repetition many times, a new cycle of reactions is built in order to get the required responses in a specific situation (Woodhead, 2010, pp. 75-76). 


\section{Rapport}

The word "rapport" is used in the field of NLP to label the relationship of understanding and trust between the communicators (O'Connor \& McDermott, 2013, p.24). Rapport is required for the communication to flow. It requires mutual respect and responsiveness between communicators. The rapport is built when positive feelings and confidence exist and no resistance to the ideas of the other occurs (Hejase, Tartozi, \& Hashem, 2015). Building rapport requires observing the reactions of the other person and identifying the key words or phrases that are used (Zulkifli, 2015). Leaders depend on rapport to improve communication, calm situations down, resolve conflicts and enhance the negotiation ability (Oberholzer, 2013).

\section{Pacing and Leading}

Pacing is an NLP technique that helps leaders and managers develop their communication skills. It refers to the flexibility of the leaders to match people's exclusive perception, behavior and vocabulary (O'Connor \& McDermott, 2013, p.30). Pacing is necessary to reinforce and strengthen rapport between the leader and the public. Leaders move to the same pace with the public and share the public's target, interests, values, and beliefs in order to guide and influence them (Zulkifli, 2015). Pacing could be achieved by choosing the appropriate vocabulary and/or body language that show appreciation and responsiveness to the viewpoints of the others. During pacing, people are used to accepting the leader' viewpoints. So, pacing functions as bridge to lead people to other prospects (Gibson, 2011, p.83-84).

\section{Modelling}

Modelling refers to the process of screening and duplicating the successful behaviors of other people (Zulkifli, 2015). Vickers and Bavister (2010, pp. 203-210) categorized modelling into implicit and explicit. Implicit modelling is a subconscious process in which the individual tries to understand others' subjective experience. Explicit 
modelling is carried out by a third person to structure other person's subjective experience. The process of modelling may start implicitly by identifying an exemplar, then explicit modelling is applied to what makes a person's behavior distinctive.

\section{Mirroring}

Mirroring is used to build rapport by creating a state of harmony between people (Casale, 2012, p. 26). Mirroring is similar to creating a mirror image to a situation or to another person's behaviors, words, tones, body language and voice patterns. Copying someone's behaviors, movements and postures creates a strong non-verbal connection with people and paves the way to accept gradual changes (Vickers \& Bavister, 2010, pp. 143-150).

\section{B. Repetition}

As neuro-linguistic programming depends mainly on sequencing and repeating the components of a system to achieve certain goals (Wełyczko, 2016), repetition is considered a core prerequisite for the success of NLP. Repetition is required for NLP techniques to have an effect; for example, repetition strengthens anchoring (Casale, 2012, p. 9), reinforces reframing (Oberholzer, 2013), sustains stronger rapport (Clabby \& O’Connor, 2004), supports modelling and mirroring (Casale, 2012, p.55) and empowers pacing and leading (Gibson, 2011, pp.83-84). Repeating a message helps the speaker to gain sympathy and create and maintain trust between the speaker and listeners. Repetition is used to convey understanding, confirm ideas, indicate counter claims, initiate conversational repair, and produce emphasis and clarity (Martlew, 2004, p.130).

Repetition is defined as the action of doing things more than once (Moore, 2015, p.19). Repetition could be non-verbal or verbal. Nonverbal repetition depends on repeating behaviors, body language, tonality and voice patterns (Vickers \& Bavister, 2010, pp. 143-150). Verbal repetition depends on the repetitive use of words and ideas. It refers to the reiteration of units and unit relations within the same text 
items (Khadair, 2016).

There are different forms of verbal repetition such as lexical, structural, semantic, morphological and phonological repetition (Khadair, 2016; \& Cui \& Zhao, 2016). Table 1 summarizes the different types of verbal repetition.

Table 1 Summary of the types of verbal repetition

\begin{tabular}{|l|l|l|l|l|}
\hline \multicolumn{2}{|l}{ Types of Repetition } \\
\hline lexical & Structural & semantic & morphological & phonological \\
\hline $\begin{array}{l}\text { single } \\
\text { item }\end{array}$ & Anaphora & Binomial & Same root & $\begin{array}{l}\text { Vowel } \\
\text { alteration }\end{array}$ \\
\hline \multirow{3}{*}{$\begin{array}{l}\text { Whole } \\
\text { phrase }\end{array}$} & Epiphora & Synonym & Suffix & Consonance \\
\cline { 2 - 5 } & Epanalepsis & Antonym & Same pattern & Assonance \\
\cline { 2 - 3 } & Anadiplosis & Hyponym & & Alliteration \\
\cline { 2 - 2 } & Antimetabole & & & $\begin{array}{l}\text { Onset } \\
\text { alteration }\end{array}$ \\
\cline { 2 - 2 } & Parallelism & & & \\
\cline { 2 - 2 } & Antithesis & & & \\
\hline
\end{tabular}

These types are discussed in the following section.

\section{Lexical Repetition}

Lexical repetition refers to the repetition of same words or the whole phrases. Lexical repetition could be divided into repeating a single lexical item or repeating a whole phrase (Khadair, 2016). Repeating a single lexical item could be simple or complex. Simple repetition of lexical items occurs when there is no great difference between the repeated lexical items; for example, play and plays (Adorján, 2013). Complex repetition takes place when the repeated items share the same lexical unit but are different formally; for example, move and movement. Another form of complex repetition is when the repeated items are similar lexically but different grammatically; for example, debate (noun and verb) and meeting (noun and verb) (Mahlberg, 2006). The second type of repetition on 
Reham Khalifa: Verbal Repetition in Neuro-Linguistic Programming

the lexical level is repeating a whole phrase within the same sentence or in more than one sentence (Reynolds, 2001), for example "When we were talking he fell asleep", and "After I visited him, he fell asleep".

\section{Structural Repetition}

Structural repetition refers to the recurrence of specific syntactic structures of sentences. Sentence structures that could be repeated include anaphora, epiphora, epanalepsis, anadiplosis, and antimetabole. It includes also parallelism and antithesis (Cui \& Zhao, 2016). "Anaphora" refers to the recurrence of the onset of successive clauses or sentences (Webber, Stone, Joshi \& Knott, 1999); for example, "what we need in the United States is not division; what we need in the United States is not hatred; what we need in the United States is not violence" (Kennedy, 1968). "Epiphora" or "Epistrophe" is the recurrence of a word or phrase at the end of consecutive sentences or clauses (Lawrence, Visser, \& Reed, 2017); for example, "If you are not free to take a decision by yourself, that's slavery. If you follow someone and you cannot move away of his shadow, that's slavery". The third type of structural repetition is "epanalepsis" which is called "echo". "Epanalepsis " refers to the repeated use of a word or group of words at the beginning and at the end of a line, sentence, or clause (Katrandjiev, Velinov, \& Radova, 2016); for example, "Revenge begets revenge." Another type of structural repetition is "anadiplosis" which means repeating a word or phrase which occurs at the end of a clause or sentence at the beginning of the next clause or sentence (Essam, 2014); for example, "Friendship is a kind of eternal love, and eternal love lasts forever." "Antimetabole" is another type of structural repetition. It refers to the recurrence of a group of words in consecutive sentences or clauses but with reversed order of words (O'Reilly \& Harris, 2017); for example, " "ask not what your country can do for you--ask what you can do for your country" (Kennedy, 1961). One more type of structural repetition is "parallelism" which refers to the repetition of the same grammatical structure of strings of 
correlated words, phrases or clauses (Mehawesh, 2013); for example, "We have to bear burdens, meet hardships, face troubles and carry responsibilities." The last type of structural repetition is "antithesis" which means to juxtapose two contradicting ideas using parallel structures (Cui \& Zhao, 2016); for example, "Committing mistakes is human, unconditioned forgiveness is divine."

\section{Morphological Repetition}

Morphological repetition refers to the recurrence of word formation. "Repetition of the word root " is a type of morphological repetition. In this type, the stem of the word is repeated (Khadair, 2016); for example, approach, approachable, approachability, approached and approaching. Another type of morphological repetition is "suffix repetition". It refers to repeating the suffix of words (Najjar, 2015); for example, suicide, matricide, infanticide and patricide. The third type of morphological repetition which is found in the Arabic language is the "pattern repetition". It refers to the repetition of the same pattern (.... فعول، فعيل، مفعال) in two words or more (Khadair, 2016); for example, ... القديج، العتبق، الرقيق، فعيق، (2) This type of repetition is commonly used in the Arabic language and it is usually used in combination with other types of repetition such as semantic repetition (Najjar, 2015).

\section{Semantic Repetition}

Semantic repetition refers to repeating words, phrases or clauses with related semantic meaning or repeating the same meaning of a line by different wording (Nadarajan, 2006). There are different types of semantic repetition. One type is the use of binomials. A "binomial" is a set of two or more words having the same form, coordinating syntactically and being related semantically; for example, the idiomatic English expressions bits and pieces, goods and materials (Norrick, 1988). The second type of semantic repetition is the use of word relations such as synonyms, antonyms, and hyponyms (Kuhl \& Anderson, 2011). An example of repeating synonymous words is "he is happy, glad and joyous". Repeating antonymous or paradoxical 
words is like "he is happy but his colleagues are sad", and repeating hyponymous words is like "bed, closet, furniture".

\section{Phonological Repetition}

Phonological repetition refers to repeating one or more phonemes in two or more words (Vaden, Muftuler, \& Hickok, 2010). Phonological repetition may occur in the form of vowel alteration, onset alteration (Nadarajan, 2006), alliteration, assonance, or consonance (Rieschild, 2006). Vowel alteration refers to the internal change of vowels to form irregular past forms like eat/ate or irregular plural like foot/feet (Even-Simkin, \& Tobin, 2011). Onset alteration is the phonological change that occurs at the beginning of two or more words like handy/dandy (Nadarajan, 2006). Alliteration refers to the repetition of the consonants at the beginning of words; for example, stiff/star/stare. Assonance is the repetition of the vowel sounds within syllables like free/flea, whereas consonance refers to the repetition of consonance which are preceded by different vowels like flash/fish/flesh (Zhang, 2005, pp.91-100).

\section{Purposes of the research}

The current study has two main purposes. The first is to investigate the types of verbal repetition used by the political leaders to optimize the effects of NLP techniques in influencing the public. The second purpose is to compare between the types of verbal repetition used by the American and Egyptian leaders. So, the results of this study would guide the political leaders to the appropriate forms of verbal repetition that could be used to seize the minds of the public.

\section{Research questions}

The current research seeks to answer the following questions:

1. What types of verbal repetition are employed by the political leaders to optimize the effects of NLP techniques?

2. What is the difference in the use of verbal repetition between Egyptian and American political leaders?

\section{Methods}

To answer the previous questions, four distinctive speeches of four 
American and Egyptian political leaders were chosen. The two American leaders were George W. Bush, the $43^{\text {rd }}$ president of the United states of America, and Barack Obama, the $44^{\text {th }}$ president of the United states of America. These two leaders were famous for their great influence over the American people (Gawenda, 2007, p. XXI). The chosen speeches of these two leaders were of the influencing speeches. Bush in his speech on March 18, 2003, tried to change the minds of the American people who were in controversy concerning the decision of the war against Iraq. He wanted to get the acceptance of the American public. Similarly, the chosen speech of Obama was delivered during the election campaign of Donald Trump who was trying to show the deficiencies in Obama's policies and stirring the American public against Obama's Democratic party. However, Obama tried hard to focus on his goal. He tried to unite the American people after a critical incident in which five police officers were killed by black citizens. He struggled to keep the unity of the American community and pacify the rage in the American street.

The two Egyptian leaders were Mohamed Hosni Mubarak, the $4^{\text {th }}$ Egyptian president, and Abdel Fattah Al-Sisi, the ex-defense minister and the $6^{\text {th }}$ Egyptian president. The chosen speech of Mubarak was delivered in critical moments in Mubarak presidential period. A great number of Egyptians were protesting against his regime and calling for his stepping down. However, he tried to change the mind of the public and convince them with his own plan. Also, Al-Sisi wanted to unite all the Egyptians to support his own vision and future plan.

The chosen speeches were analyzed based on content analysis, a textual analysis approach which is used to analyze the embedded characteristics and times of occurrences of a specific linguistic feature (Frey, Botan, \& Kreps, 1999, p. 236). This methodology is helpful in gathering and analyzing information related to the chosen content and reaching the most likely interpretations that might be drawn of that text (McKee, 2001). Therefore, the contents of the four speeches were 
analyzed quantitatively and qualitatively based on the content analysis approach to disclose the NLP techniques, the forms of repetition and the frequency of using these forms.

\section{Analysis}

\section{Bush's speech on Iraq on March 18, 2003}

On March 18, 2003, George W. Bush delivered a 1764-word speech to the American people to convince them of the benefits of the war against Iraq. In this speech, Bush employed different NLP techniques such as rapport, anchoring, reframing and pacing and leading. In order to strengthen the effects of these NLP techniques, Bush employed different forms of verbal repetition which had a great effect on making Bush win the support of the Congress (Eichenberg, $\&$ Stoll, 2006). These forms of repetition are illustrated in the following section.

\section{Lexical repetition}

Bush employed the two main kinds of lexical repetition. He used the repetition of single lexical items many times as indicated in Table 2.

Table 2 Repetitions of Single Lexical Items in Bush's speech

\begin{tabular}{|l|c|c|c|}
\hline Lexical Item & Repetitions & Lexical Item & Repetitions \\
\hline Terror & 15 & Peace & 5 \\
\hline War & 14 & Disarmament & 4 \\
\hline Saddam Hussein & 11 & Allies & 4 \\
\hline Threat & 10 & American & 4 \\
\hline Force & 9 & Attack & 3 \\
\hline Weapon & 9 & Liberty & 3 \\
\hline Terrorist & 8 & Enemies & 3 \\
\hline Disarm & 7 & Aggression & 3 \\
\hline Peaceful & 7 & Coalition & 3 \\
\hline America & 7 & Destroy & 3 \\
\hline Disarm & 7 & Defend & 2 \\
\hline Inspectors & 6 & Biological & 2 \\
\hline Free & 6 & Nuclear & 2 \\
\hline Destruction & 6 & Tyrant & 2 \\
\hline Resolution & 5 & Peacefully & 2 \\
\hline Danger & 5 & Confrontation & 2 \\
\hline Dictator & 5 & Diplomacy & 2 \\
\hline
\end{tabular}


Also, George Bush utilized the phrase repetition in his speech to the Americans. He repeated "other nations" two times, "mass destruction" five times, "UN security council" two times, "Iraqi regime" three times, "Iraqi people" three times, "Iraqi military" four times, and "the United States and other nations" two times.

\section{Structural repetition}

Different types of structural repetition were employed in Bush's speech about Iraq. Bush utilized structural anaphora about six times, for example, "we will deliver the food", "we will tear down the apparatus of terror" and "we will help you build a new Iraq". In addition to the use of anaphoric structures, Bush employed parallelism about 12 times, for example, "Do not destroy oil wells" and "do not obey any command".

Structural epiphora was employed thrice within Bush's speech, for example, "these governments share our assessment of the danger" and "no resolve to meet it". Structural anadeplosis was employed only once in Bush's speech, "the United States and other nations ...... to disarm the Iraqi regime" and "that regime pledged to reveal...". Also, the antimetabole was employed once, "Saddam Hussein and his sons must leave Iraq within 48 hours" and "all foreign national should leave Iraq immediately".

\section{Morphological repetition}

The two types of morphological repetition were employed in Bush's speech. Root repetition was utilized about 21 times, for example, acting/inaction and peace/peaceful/peacefully. Suffix repetition was employed about 14 times, for example, genocide/suicide and electronically/systematically.

\section{Semantic repetition}

Different types of semantic repetition were employed within Bush's speech. Bush used binomial more than 8 times, for example, "attack the innocent and destroy the peace". Additionally, Bush 
Reham Khalifa: Verbal Repetition in Neuro-Linguistic Programming 99

employed synonyms about five times, for example, "horror and terror", "thugs and killers" and "hostility and aggression. Also, Bush employed antonyms about five times, for example, "threat and peace" and "public and private". In his speech on Iraq, Bush utilized hyponymy as a kind of semantic repetition about four times; for example, "nuclear weapons, biological weapons, Sarin Nerve gas, VX Nerve gas, chemical weapons and ballistic missiles", and "chemical terror, biological terror and nuclear terror".

\section{Obama's speech at Dallas Police Memorial on July 12, 2016}

On July 12, 2016, Barack Obama delivered a 3723-word speech to mourn the passing of five police officers who were killed in clashes with black protesters in Dallas. Obama, throughout his speech, tried to unite the nation and control the rage everywhere. Therefore, Obama employed different NLP techniques such as rapport, anchoring and pacing and leading to influence the American people. In order to support the NLP techniques in this speech, Obama employed different types of verbal repetition which helped pacify the rage of the families of the police officers and the black people's feelings of oppression and hatred (Hennessy-Friske, 2016).

\section{Lexical Repetition}

In his speech in Dallas, Obama employed the different types of lexical repetition. He used single item repetition many times as indicated in Table 3. 
Table 3 Repetitions of Single Lexical Items in Obama's Speech

\begin{tabular}{|c|c|c|c|c|c|}
\hline $\begin{array}{c}\text { Lexical } \\
\text { item }\end{array}$ & Repetitions & $\begin{array}{c}\text { Lexical } \\
\text { item }\end{array}$ & Repetitions & $\begin{array}{c}\text { Lexical } \\
\text { item }\end{array}$ & Repetitions \\
\hline Police & 38 & True & 4 & Hope & 6 \\
\hline Dallas & 17 & Hurt & 4 & Serve & 5 \\
\hline Protest & 15 & Kids & 4 & Community & 5 \\
\hline Work & 14 & Honor & 3 & Job & 5 \\
\hline Heart & 14 & Thursday & 3 & Law & 5 \\
\hline People & 12 & Decent & 3 & Change & 4 \\
\hline Family & 11 & Duty & 3 & Dismiss & 4 \\
\hline Country & 11 & Honest & 3 & Match & 4 \\
\hline Kill & 10 & Truth & 3 & Lost & 4 \\
\hline America & 10 & Protect & 3 & Keep & 2 \\
\hline Americans & 8 & Pray & 2 & Uniform & 2 \\
\hline Cop & 8 & Partner & 2 & Inadequate & 2 \\
\hline Suffering & 8 & Democracy & 2 & Weep & 2 \\
\hline White & 8 & Despair & 2 & Sustain & 2 \\
\hline Black & 8 & Divide & 2 & Perfectly & 2 \\
\hline Today & 7 & Wounded & 2 & Authority & 2 \\
\hline Words & 7 & Shaken & 2 & Hero & 2 \\
\hline Mourn & 6 & Loss & 2 & Tension & 2 \\
\hline Dangerous & 6 & & & & \\
\hline Addition & & & & \\
\hline
\end{tabular}

Additionally, Obama repeated a whole sentence such as "our sufferings there is glory, because we know that suffering produces perseverance; perseverance, character; and character, hope". Also, he repeated a number of phrases as indicated in Table 4.

Table 4 Number of Repeated Phrases in Obama's speech

\begin{tabular}{|l|l|l|l|}
\hline Phrase & Repetitions & Phrase & Repetitions \\
\hline Police officer & 13 & Men and women & 2 \\
\hline $\begin{array}{l}\text { Answered the } \\
\text { call }\end{array}$ & 6 & We cannot match & 2 \\
\hline $\begin{array}{l}\text { With an open } \\
\text { heart }\end{array}$ & 5 & $\begin{array}{l}\text { Because of what I've } \\
\text { seen }\end{array}$ & 2 \\
\hline Dallas Police & 5 & I've seen how & 2 \\
\hline Thank you & 4 & In this audience & 2 \\
\hline Peaceful protest & 3 & People of Dallas & 2 \\
\hline
\end{tabular}


Reham Khalifa: Verbal Repetition in Neuro-Linguistic Programming

\section{Structural Repetition}

In his speech, Obama employed different types of structural repetition. He used anaphora about 19 times, for example, "I'm here to say we must reject such despair", and "I'm here to insist that we are not as divided as we seem". Obama employed parallel structures about 43 times, for example, "we turn on TV", and "we surf the internet". Additionally, Obama used antimetabole about 10 times, for example, "our entire way of life in America depends on the rule of law", and " the maintenance of that law is a hard and daily labor". One more type of structural repetition was epanalepsis. It was utilized about three times, for example, "suffering produces perseverance", and "perseverance produces character". The last type of structural repetition used by Obama was epiphora. It was utilized about three times, for example, "see, that's America I know", and "I see what's possible when we recognize .... that's America I know".

\section{Morphological Repetition}

Obama employed different types of morphological repetitions in his speech in Dallas. He employed root repetition about 35 times, for example, simple/simply and perfect/imperfection/perfectly. Similarly, Obama employed suffix repetition about 30 times, for example, majority/minority and presidency/expediency.

\section{Semantic Repetition}

In his speech in Dallas, Obama employed different types of semantic repetition. He used binomials about six times, for example, "all of it left us wounded and hurt". Also, he repeated synonyms three times, for example, biased/bigoted, and slavery/subjugation. Moreover, Obama employed antonyms 5 times in his speech, for example, good/bad, and wrong/right. Furthermore, Obama used hyponyms two times, for example, black, white, Hispanic, Asian, Native American, and Middle Eastern descent which are all hyponyms of Americans. 


\section{Phonological Repetition}

In his speech in Dallas, Obama employed only one type of phonological repetition. He employed vowel alteration about nine times, for example, know/knew, and man/men.

\section{Mubarak's speech on February 1, 2011}

On the first of February 2011, Mubarak gave a 733-word speech to the Egyptian people. He tried to persuade them to accept his own plan and stop protesting. In this speech, Mubarak employed different NLP techniques such as rapport, anchoring and pacing and leading. To fortify these NLP techniques, Mubarak employed different types of verbal repetition which had a great influence on the public. Before this speech, all the people were against Mubarak. After this speech, the collective mind of the Egyptian people was divided (Korany, 2014, p. 262). The types of verbal repetition used in Mubarak's speech are presented in the following.

\section{Lexical repetition}

Mubarak utilized the two types of lexical repetitions. He employed the repetition of single lexical items as indicated in Table 5.

Table 5 Repetitions of Single Items in Mubarak's Speech

\begin{tabular}{|c|c|c|c|}
\hline Lexical Item & Repetitions & Lexical Item & Repetitions \\
\hline "مصر /Egypt" & 17 & $\begin{array}{l}\text { البرلمان" } \\
\text { /"Parliament" }\end{array}$ & 3 \\
\hline " شعب /"People" & 15 & "Anarchy"/ فوضي & 2 \\
\hline "Homeland"/وطن & 12 & "مشروعة "Legal" & 2 \\
\hline "Stability"/ استقرار / & 5 & "Retrieving" "استعادة/" & 2 \\
\hline "Security"/ أمن & 4 & $\begin{array}{l}\text { مصريين" } \\
\text { /"Egyptians" }\end{array}$ & 2 \\
\hline "Peaceful"/ سلمي & 4 & "Elections" /انتخابات " & 2 \\
\hline دستور & 4 & $\begin{array}{l}\text { حكومة"Government" } \\
\text { /"Govent }\end{array}$ & 2 \\
\hline "/"Authority" سلطة & 3 & "legitimacy"/ شرعية & 2 \\
\hline
\end{tabular}

In addition to single item repetition, Mubarak repeated some phrases. He repeated twice the phrases "المطالب المشروعة/Legal Demands", "الدعوة للحوار/The call for dialogue", "الانتقال السلمي/The 
Peaceful Transition", "تعديلات دسنورية/ Constitutional amendments", استعادة الامن "The Armed Forces", القوات المسلحة" , الأخوة المواطنون"

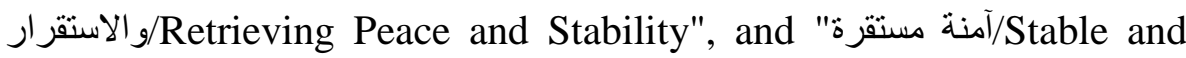
Secure". Also, Mubarak repeated the phrase "القوي السياسية/The Political Forces" thrice in his speech.

\section{Structural Repetition}

Mubarak employed different types of structural repetition. He employed the anaphora once "..... ستخرج مصر من الظروف الراهنة Egypt will emerge from the current circumstances..." and " سيخرج منها Egyptian People will emerge ...". He employed antimetabole three times, for example, "هناك من القوي السياسية من رفض هذه الدعوة للحوار" There are some political Forces that rejected this call for dialogue" and بالنظر لهذا الرفض لدعوتي للحوار / As for rejecting my call for dialogue". Also, Mubarak repeated parallel structures eight times, for example, " ستخرج مصر من الظروف الراهنة أقوي Egypt will emerge stronger from the current circumstances" and "سنرج شنعبنا منها أكثر وعيا / Our People will emerge more aware from the current circumstances".

\section{Morphological Repetition}

In his speech on February 1, 2011, Mubarak utilized various types of morphological repetition. He repeated words of the same root about five times, for example, "Legal مشروعة/legitimacy شرعية/ whose root is شuرع. Mubarak repeated words with the same suffix many times. For example, He repeated about ten words of the same suffix " like أوقات أتخابات - imes elections - تظاهرات demonstrations". Also, he repeated words of the same suffix "ينين about seven times, for example," مصربين Egyptians - مواطنين Citizens - قوانين Laws". Likewise, Mubarak repeated other four words of the same suffix "

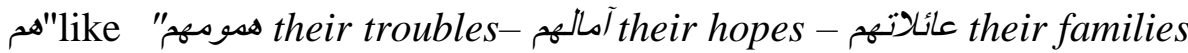
- تطلعاتهر their aspirations". Similarly, Mubarak repeated ten words of the same suffix "-"like "مدنها its cities - أقباطه its Coptic - مسلميه its Muslims - أرضه its land". As well, Mubarak employed words of the 
same pattern. For example, he repeated words of the same pattern سلب/نهب/قطع three times like. Moreover, he repeated words of the same pattern "تفعل" two times like تفرض/تطرح

\section{Semantic Repetition}

In his speech on February 1, 2011, Mubarak employed different types of semantic repetition. He used binomials five times, for / أمن و/ستقرار" / Elegant and civilized", and راق ومتحضر" Symple, Security and stability". Synonyms were utilized thrice, for example, " / نز/هة وشرف " honesty and honor". Antonyms were used four times, for example, "الفوضى "نفرف

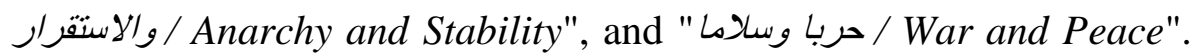
Also, hyponymy was utilized three times, for example, " لأبناء الثعب وسلا بفلاحيه وعماله ومسليه أقباطه شيوخه وشبابه peasants, workers, Muslems, Christians, Youth and Old people". In the previous examples Egyptian people are divided into peasants, workers, Muslims, Christians, youth and old people.

\section{Phonological Repetition}

Mubarak employed phonological repetition in different positions. He used assonance by repeating the same final vowel /ya/ in words

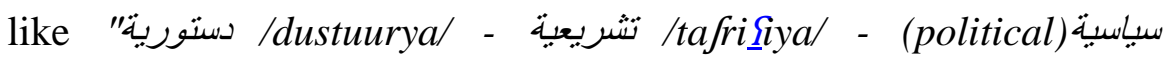

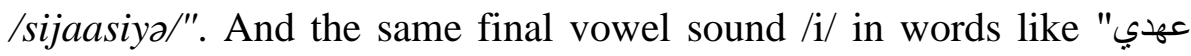

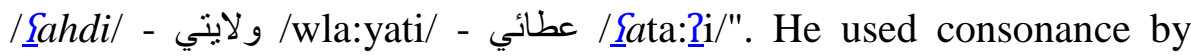
repeating the last consonant sound, /n/, in words like "

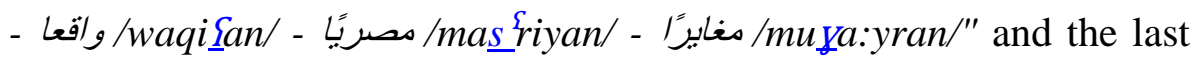

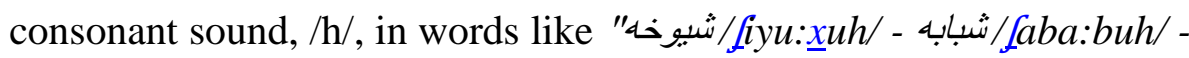
. شعب

\section{IV.Al-Sisi's Speech on July1, 2013}

On the first of July, 2013, Al-Sisi gave a 411-word speech to the Egyptian people. He tried to convince and urge all the political forces to unite and respect people's will. Also, he tried to convince protesters in Al-Tahrir square that the Armed Forces was backing them up and 
their needs would be satisfied. In his speech, Al-Sisi employed different NLP techniques such as rapport, anchoring and mirroring in order to fulfil his target. In order to support these NLP techniques, AlSisi employed different forms of repetition which had a great effect on the audience who celebrated in Al-Tahrir square (Saad Eldeen, 2013).

\section{Lexical Repetition}

Al-Sisi utilized different types of lexical repetition. He repeated single lexical items as indicated in Table 6.

Table 6 Repetitions of Single Lexical Items in Al-Sisi's Speech

\begin{tabular}{|c|c|c|c|}
\hline Lexical Item & Repetitions & Lexical Item & Repetitions \\
\hline "people" / الشعب & 8 & $\begin{array}{c}\text { /وطن } \\
\text { "Homeland" }\end{array}$ & 3 \\
\hline 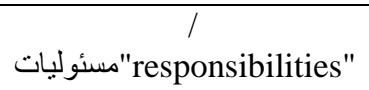 & 6 & $\begin{array}{l}\text { / "getting } \\
\text { out" }\end{array}$ & 3 \\
\hline "all" / جميع " & 5 & $\begin{array}{c}\text { / وطن } \\
\text { "Homeland" }\end{array}$ & 3 \\
\hline "patriotism" /وطنية & 4 & $\begin{array}{c}\text { / لزاما / } \\
\text { "obligatory" }\end{array}$ & 2 \\
\hline "danger" / خطر & 4 & $\begin{array}{l}\text { مهلة / "time } \\
\text { limit" }\end{array}$ & 2 \\
\hline
\end{tabular}

In his speech, Al-Sisi repeated different phrases. He repeated "الثعب الأبي" Armed Forces" seven timesle of pride"

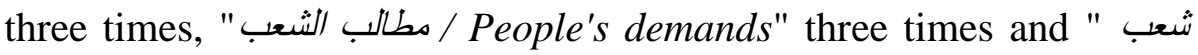
/ Egyptian people" three times.

\section{Structural Repetition}

Al-Sisi used anaphora in sentences like "the Armed Forces as a

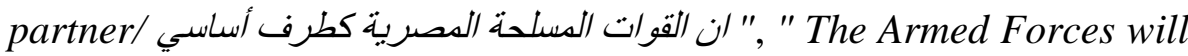

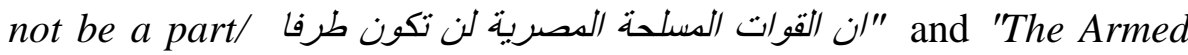

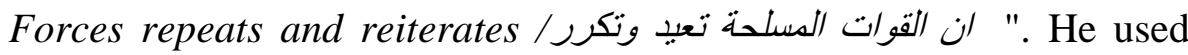

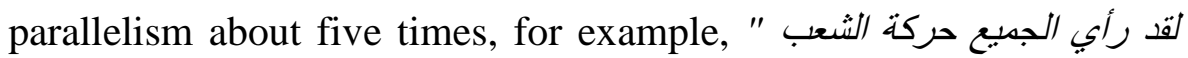
الدصري All the people saw the movement of the Egyptian people" and " سدعو/ صوتهـ / All the people heard his voice" 


\section{Morphological repetition}

Al-Sisi employed different types of morphological repetition in his speech. He used words of the same root about six times like "حذرنا (we (w) حذر (we warned) " and " نحذر (We warn)" of the same root " حذر (warn) ". In his speech, Al-Sisi repeated words of the same suffix. He reiterated words that ended with the suffix "ات", that was used to form feminine plural, like "مسئوليات - مظاهرات - procedures responsibilities

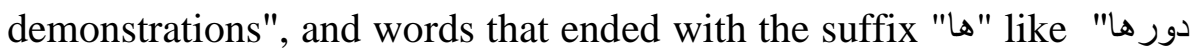
its role - شعبها its people - مسئونها its responsibilities". Likewise, Al-Sisi repeated words that have same pattern. He used the words " "

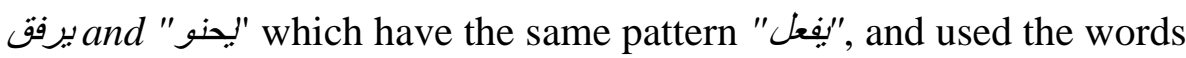
"تعبي", "تكرل" "تكرر" andich have the same pattern "تفعل".

\section{Semantic Repetition}

In his speech on July 1, 2013, Al-Sisi employed different types of semantic repetition. He used binomials about four times, for example, " / / / الانقسام والتصارع" / divis voice and his call", and and conflict". He also utilized synonyms eight times, for example, "تعيد الإخلاص والتفاني" sincerity and dedication". Likewise, he used antonyms twice, for example, تقصر في تحمل مسئولياتها/ متحملين " Agreement/division" and - تو/قق/انقسام" - take the responsibility/do not take the responsibility". Additionally, Al-Sisi used hyponymy two times. He used different branches of interest level, for example, "الاهنمام علي المستوي الداخلي the interest on the internal, national, international level". Also, he mentioned different branches of burdens, moral and psychological "عبء نفسي وأخلاقي".

\section{Phonological Repetition}

In his speech to the Egyptian people, Al-Sisi employed various types of phonological repetition. He used consonance in words like "

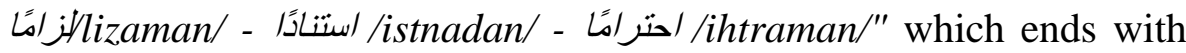
the same consonant sound /n/. In addition, he used assonance in words like "الوطنية - التاريخية/altarixatanya/" that ends with the same 
vowel sound /ya/. Moreover, Al-Sisi employed onset alteration in words like "يجد/jagid/"and "تجد/tagid/".

\section{Findings and Discussion}

Analyzing the speeches of the four political leaders revealed that all of them employed different NLP techniques to direct the public to a specific decision. The four leaders employed rapport, anchoring, mirroring, reframing and pacing and leading.

To accentuate the effects of the used NLP techniques and to succeed in directing the public, the four political leaders employed different forms of verbal repetition. Bush employed repetition 133 times per 1000 words, Obama utilized repetitive forms 153 times per 1000 words, Mubarak used repetition 221 times per 1000 words, and Al-Sisi employed repetition 219 times per 1000 words. The analysis of the four speeches indicated that the Egyptian leaders employed repetitive forms more than the American leaders. This could be attributed to the nature of the Arabic language in which repetition not only is used to influence and affect others' beliefs (Hamadouche, 2013), but also is considered a textual cohesive tool that manifests the stylistic creativity of the speaker or writer (Lahali, 2012). On the other hand, repetition is used in the English language to intensify and strengthen the influence of words on the audiences (Lahali, 2012).

The results revealed that lexical repetition is the most frequently used form of repetition in the speeches of the four political leaders. Reynolds (2001) explained that the excessive use of lexical repetition created a sense connectedness between old and new information presented in the speech. This connectedness helps the audience concentrate on the proposed ideas and therefore could be directed and guided towards the required decisions. As for Bush, the most repeated lexemes were terror, war, Saddam Hussein, threat and mass destruction. By repeating these lexemes, Bush strengthened the idea that Saddam Hussein is a source of terror to all nations and war is a must to avoid Saddam's threat of mass destruction. Concerning 
Obama, the most repeated lexical items were police, police officers, Dallas, Protest, heart, families and answered the call. By repeating such lexical items, Obama tried to control the rage of the street. $\mathrm{He}$ directed the attention of his audience to the valuable role of the police officers whose job is to answer the call of all Americans and protect them from dangers. Also, Obama referred to the human side of the police officers as having hearts and families like any other citizen. With regard to Mubarak, the most frequently repeated lexical items were Egypt, People, homeland and stability. Mubarak tried to direct the attention of the audience to the necessity of stability to protect Egypt, the homeland, and its people from anarchy. With reference to Al-Sisi, the most repeated items were people, Armed Forces, all, patriotism and danger. Al-Sisi tried to influence the audience by focusing on the shared responsibilities between all the Egyptian people and the Armed Forces to avoid danger.

Conversely, phonological repetition was less common than any other form of repetition. This result coordinated with the findings of Algashamy (2009) who concluded that phonological repetition was less common than lexical repetition. Phonological repetition hardly occurred in Bush's speech and scored 0.2\% in Obama's speech. Mubarak employed phonological repetition with a percentage $1.8 \%$, whereas Al-Sisi employed it with a percentage of 1.2\%. Although the phonological repetition was not common in the speeches of the American leaders, it was used but with a small percentage in the speeches of the Egyptian leaders. This could be attributed to the nature of the Arabic language that depends on the use of diacritics. So, phonological repetition helps identify the Arabic words (Bentin, 1989).

Analysis of the results revealed that the four political leaders employed structural repetition with extremely similar percentages (Bush 1.3\%, Obama 1.5\%, Mubarak 1.1\% and Al-Sisi 1.7\%). The use of structural repetition was employed less than lexical and 
morphological repetition. This finding is concurrent with the findings of Healey, Purver and Howes (2016) who found out that structural repetition was not used excessively in speaking because speakers tend to vary their sentence structure to show their creativity in speaking and to attract the attention of the audience.

The most employed form of structural repetition in the speeches of the four leaders was parallelism. Bush used parallel structures twelve times. He repeated the structure "subject + will be + past participle" eight times, five of them were to assure the American people that every measure to protect them was taken, for example, "this danger will be removed". The previous structure was used three times to warn the Iraqi army, for example, "war crimes will be prosecuted". The negative imperative "do not + inf." was employed four times to threaten the Iraqi soldiers from fighting the coalition army, for example, "do not obey any command". As for Obama, he employed parallel structures 43 times. He used the structure "subject +verb + to inf." 28 times, for example, "he liked to post" and "they try to match". Also, he used the structure "we're here to +inf." six times, for example, "we're here to honor" and "we're here to grieve". Similarly, he used the structure "I've +pp." nine times, for example, "I've seen" and "I've experienced". Concerning Mubarak, he used parallelism eight times. He used the structure "past +subject" two times, for example, "I appointed a vice president" and "I started to form a new government", and the structure "present + subject" four times, for example, "protect the legitimacy" and "respect the constitution". Mubarak reiterated the structure "subject +future" two times, for example, "it will get out" and "we will get out". With regard to AlSisi, he used parallel structures five times. He employed the structure "plural subject +past verb" three times, for example, "they saw your movement" and "they heard your sound", and the structure "subject +will not + inf." two times, for example, "the Armed Forces will not be a part" and "the Armed Forces will not accept to deviate". The four 
leaders focused on the use of parallelism because of its distinctive effect on people's consciousness. This result is in accordance with Mehawesh (2013) who attributed the use of parallelism in advertising texts to its role in reminding people of what is said and in emphasizing the meaning. Also, parallelism makes the speech cohesive (Mehawesh, 2013).

As for the morphological repetition, it was used variously by the four leaders. It was more frequent in the speeches of Al-Sisi (7.1\%) and Mubarak (5.6\%) and it was less common in the speeches of Bush (2\%) and Obama (1.7\%). This discrepancy in the use of morphological repetition could be due to the nature of the Arabic language as a Semitic Language that depends on root-pattern schemes. The Arabic language is highly inflected (Najjar, 2014). Arabic words are constituted by combining word roots to pattern variables. Although Arabic affixes are fewer than English affixes, the Arabic affixes could be concatenated; for example, adding the definite article" to Arabic stems like "ال + حياة= الحياة and adding the object

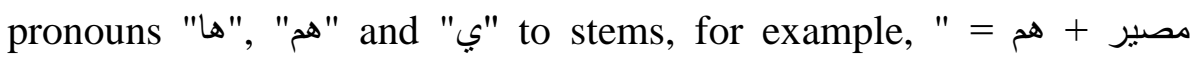
"مصير + ها= مصير ها/مصير + ى = مصيري/مصير هم "هl-Sughaiyer \& AlKharashi, 2004). This possibility widened the use of Arabic affixes (Zaraket \& Makhlouta, 2012). So, the morphological features in Arabic are more versatile than in English; the English language is not based on root-pattern schemes or on the concatenating feature. As a result, the morphological repetition existed in the speeches of the Egyptian speakers more than the speeches of the American speakers.

Concerning the employment of the semantic repetition, it was found that the four political leaders were not similar in their use of the semantic repetition. The results revealed that Al-Sisi employed semantic repetition more than any other leader. Because the use of the semantic repetition has an explicit effect on the short term memory of the hearers (Meltzer et al, 2016), Al-Sisi might have tried to influence the public by varying the use of word relations that affect the short 
term memory of the audience. The most common used word relations in Al-Sisi's speech were binomials, synonyms and hyponyms. Mubarak (1.9\%) and Bush (1.3\%) were not so different in their use of the semantic repetition. They concentrated on the use of antonyms. Although Obama was the least in his use of the semantic repetition $(0.8 \%)$, he also depended mainly on antonyms. The use of antonyms deepens the expressive nature of the vocabulary. Therefore, antonyms strengthen the presented ideas and enrich the argument (Gjergo \& Delija, 2014).

\section{Conclusion}

The current study sought to answer two main questions. The first question was: "What types of verbal repetition are employed by the political leaders to optimize the effects of NLP techniques?" The analysis of the results affirmed that political leaders employed different types of verbal repetition to be persuasive and to influence the public. They employed the two forms of lexical repetition, single item repetition and phrase repetition. Also, different forms of structural repetition were employed such as anaphora, parallelism, epiphora, anadiplosis and antimetabole. The political leaders used the three forms of morphological repetition. They reiterated words that have the same root, the same suffix and the same pattern. The political leaders used repeatedly different semantic relations such as binomial, synonym, antonym and hyponym. As for the phonological repetition, it was found that vowel alteration, assonance and consonance were employed by the political leaders.

The second question was: "What is the difference in the use of verbal repetition between Egyptian and American political leaders?". The results revealed that verbal repetition was employed in the speeches of the Egyptian and American political leaders. However, verbal repetition was used more frequently in the speeches of the Egyptian leaders. It could be attributed to the nature of the Arabic language in which repetition is a tool to create a cohesive text and to 
show stylistic creativity.

Additionally, the results showed that lexical repetition was the common form in the speeches of the Egyptian and American leaders. Conversely, phonological repetition was the less frequently used type of repetition. It was employed by the Egyptian leaders more than the American leaders. Similarly, morphological repetition was used by the Egyptian leaders more than the American leaders. This could be related to the existence of the root-pattern schemes in the Arabic language. The results indicated that the Egyptian and American leaders employed structural repetition with relatively similar percentages. However, the four leaders were not similar in their use of semantic repetition. Al-Sisi used semantic repetition more than the others, whereas Obama was less likely to use semantic repetition.

In sum, different forms of repetition were employed by the Egyptian and American leaders to strengthen the effects of NLP techniques used and to have a greater influence on the public. There is little discrepancy in the percentages of using each repetition form by each political leader.

\section{Limitations}

This study dealt with only one linguistic feature which is repetition. Other linguistic features such as metaphors, figures of speech and rhetoric devices were not manipulated. Additionally, this study focused on analyzing the forms of verbal repetition. Non-verbal repetition was not investigated. Also, exploring the use of NLP techniques in the field of the political leadership was limited to the speeches of only 4 leaders; two Egyptian and two American.

\section{Further research}

Further research could investigate the effects of using verbal repetition on each NLP technique by conducting an experimental study in a laboratory. Other research could manipulate the influence of other linguistic features on the use of NLP techniques. Also, the 
Reham Khalifa: Verbal Repetition in Neuro-Linguistic Programming 113

effects of non-verbal repetition on the use of NLP could be further explored. Moreover, a comparison between the effects of using verbal and non-verbal repetition to strengthen the use of NLP techniques could be set. Other research may enlarge the sample of the political leaders to be able to generalize the results. 


\section{References}

Adorján, M. (2013). Explorations in Lexical Repetition Analysis: The Outcomes of Manual vs. Computer Automated Research Methods. WoPaLP, Vol. 7, pp. 128.

Al-Gashamy, R. A. (2009). The Use of phonological Repetition in the Texts of English Proverbs. Available, on January 20, 2017, from www.academia.edu/7487425/The_Use_of_phonological_Repetition.

Al-Sughaiyer, I. A. \& Al-Kharashi, I. A. (2004). Arabic Morphological Analysis Techniques: A Comprehensive Survey. Journal of the American Society for Information Science and Technology, Vol. 55, No. 3, pp.189-213.

Bashir, A., \& Ghani, M. (2012). Effective Communication and Neurolinguistic Programming. Pak. J. Commer. Soc. Sci., Vol. 6, No. 1, pp. 216-222.

Bentin, S. (1989). Orthography and phonology in lexical decision: Evidence from repetition effects at different lags. Journal of Experimental Psychology: Learning, Memory, and Cognition, Vol.15, pp. 61-72

Blaney, C. B. (2014). The Language of Political Persuasion: Three Case Studies Exploring "Rhetoric of Coercion” (Master Thesis). Johns Hopkins University, Baltimore, Maryland, USA.

Bowman, C., Ronch, J., \& Madjaroff, G. (2010). The power of language to create culture. Retrieved, on 30/4/2018, from http://www.pioneernetwork.net/Data/Documents/PowerofLanguage7-9-1.pdf.

Brower, H. H., Fiol, C. M., \& Emrich, C. G. The Language of Leaders (2007). Journal of Leadership Studies, Vol. 1, No. 3, pp. 67-80.

Casale, P. (2012). NLP Secrets: Upgrade Your Mind with Neuro-Linguistic Programming. New Zealand: Creative Media NZ Ltd.

Clabby, J., \& O’Connor, R. (2004). Teaching Learners to Use Mirroring: Rapport Lessons from Neuro-linguistic Programming. Family Medicine, Vol.36, No. 8, pp.541-543

Cui, Y., \& Zhao, Y. (2016). Repetition of Sound, Structure, and Meaning: A Study of Poeticising Strategies in English-Chinese Advertisement Translation. The Journal of Specialised Translation, Issue 26, pp.136-150.

Eichenberg, R. C., \& Stoll, R. J. (2006). War President: The Approval Ratings of George W. Bush. Journal of Conflict Resolution, Vol. 50, No. 6, pp. 783-808.

Essam, B. A. (2014). Toward A Successful Translation of The "Reduced" Anadiplosis in The Quranic Verses. Advances in Language and Literary Studies, Vol. 5, No. 6, pp. 24-30.

Even-Simkin, E., \& Tobin, Y. (2011). Phonological Aspects of Internal Vowel Alternation in English. ICPhS, Vol. 17, pp. 647-650.

Frey, L., Botan, C., \& Kreps, G. (1999). Investigating Communication: An Introduction to Research Methods. ( $2^{\text {nd }}$ Ed.) Boston: Allyn \& Bacon.

Gawenda, M. (2007). American Notebook: A Personal and Political Journey. Melbourne, Australia: Melbourne University Press.

Gibson, B. (2011). The complete Guide to Understanding and Using NLP: Neuro- 
Linguistic Programming explained simply. Florida, USA: Atlantic Publishing Group.

Gjergo, E. S., \& Delija, S. (2014). The Role and Function of the Antonyms in Language Mediterranean Journal of Social Sciences, Vol. 5, No. 16, pp. 703705.

Hamadouche, M. (2013). Intercultural Studies in the Arab World from a Contrastive Rhetoric Perspective. AWEJ, Special Issue on Translation, No. 2, pp.181-188

Healey, P., Purver, M. \& Howes, C. (2016). Structural Repetition in Restricted and Unrestricted Dialogue. Twenty-sixth Annual Meeting of the Society for Text \& Discourse, Kassel, Hesse, Germany.

Hejase, H. J., Tartozi, M. I., \& Hashem, F. (2015). Neuro-Linguistic Programming and Leadership: An Exploratory Study on Lebanese Management. European Journal of Business and Social Sciences, Vol. 4, No. 09, pp. $121-155$.

Hennessy-Friske, M. (2016, July 12). Dallas Black Police Assn. president: Speech was 'magnificent'. Los Angeles Times. Available, on December 16, 2017, from http://www.latimes.com/nation/la-live-updates-obama-speak-service-slaindallas-officers-20160712-htmlstory.html

Johnson, P. H. (2012). Opening Minds Using Language to Change Lives. Portland, Maine: Stenhouse Publishers.

Katrandjiev, H., Velinov, I., \& Radova, K. (2016). Usage of Rhetorical Figures in Advertising Slogans. Trakia Journal of Sciences, Vol. 14, No 3, pp 267-274.

Kennedy, R. F. (1961). Inaugural Address, 20 January 1961. Available, on December 15, 2017, from https://www.jfklibrary.org/AssetViewer/BqXIEM9F4024ntFl7SVAjA.aspx

Kennedy, R. F. (1968). Statement on Assassination of Martin Luther King, Jr. Available, on December 15, 2017, from https://www.jfklibrary.org/Research/Research-Aids/Ready-Reference/RFKSpeeches/Statement-on-the-Assassination-of-Martin-Luther-King.aspx

Khadair, S. J. (2016). Repetition as a Rhetorical Device in the Political Speeches of Three Egyptian Presidents: Mubarak, Morsi Al-Sisi, A Comparative Translation Study (Master Thesis). An-Najah National University, Nablus, Palestine.

Korany, B. (2014). A Microcosm of Arab Spring: Sociology of Tahrir. In Kamrava, Mhran (Ed.). Beyond the Arab Spring: The Evolving Ruling Bargain in the Middle East (pp. 249-276). Oxford, UK: Oxford University Press.

Kuhl, B. A., \& Anderson, M. C. (2011). More is not Always Better: Paradoxical Effects of Repetition on Semantic Accessibility. Psychon Bull Rev, Vol. 18, pp. 964-972.

Lahlali, E. (2012). Repetition and Ideology in Nasrallah's Political Speeches. Arab Media and Society, Vol. 15, pp.1-13.

Lawrence, J., Visser, J. \& Reed, C. (2017). Harnessing Rhetorical Figures for Argument Mining. Argument \& Computation, Vol. 8, pp. 289-310.

Mahlberg, M. (2006). Lexical Cohesion Corpus Linguistic Theory and its Application in English Language Teaching. International Journal of Corpus 
Linguistics, Vol. 11, No.3, pp. 363-383.

Martlew, C. (2004). Leadership Recharged! Business Leadership and Organizational Architecture. Leicester, UK: Troubador Publishing.

McKee, A. (2001) A beginner's guide to textual analysis. Metro Magazine, pp. 138149.

Mehawesh, M. I. (2013). Grammatical Parallelism in the Translation of Advertising Texts with Particular Reference to English and Arabic. Asian Social Science, Vol. 9, No. 10, pp.254-263.

Meltzer, J. A., Rose, N. S., Deschamps, T., Leigh, R. C., Panamsky, L., Silberberg, A., Madani, N., \& Kira A. Links, K. A. (2016). Semantic and phonological contributions to short-term repetition and long-term cued sentence recall. Mem Cogn, Vol. 44, pp.307-329.

Moore, N. J. (2015). Repetition in Hebrew: Plurality and Singularity in the Letter to the Hebrew, its Ancient Context, and the Early Church. Tübingen, Germany: Mohr Siebeck.

Nadarajan, S. (2006). A Crosslinguistic Study of Reduplication. Arizona Working Papers in SLAT, Vol.13, pp. 39-53.

Najjar, I. (2015). 'Repetition' in Arabic-English Translation: The Case of "A Drift on the Nile". International Journal of Foreign Language Teaching \& Research, Vol. 3, Issue 10, pp. 24-34.

Newberg, A., \& Waldman, M. R. (2013). Words Can Change your Brain: 12 Conversational Strategies to Build Trust, Resolve Conflicts and Increase Intimacy. New York, USA: Penguin Group.

Norrick, N. R. (1988). Binomial Meaning in Texts. Journal of English Language, Vol. 21, No. 1, pp. 72-87.

O'Reilly, C., \& Harris, R. A. (2017). Antimetabole and Image Schemata: Ontological and Vector Space Models. The Proceedings of the Joint Ontology Workshops (JOWO 2017), Bozen-Bolzano, Italy, September 21-23, Vol. 2015, paper 3.

Oberholzer, C. (2013). The Role of Neuro Linguistic Programming in Improving Organisational Leadership through Intrapersonal Communication Development (PHD thesis). University of Pretoria, South Africa.

O'Connor, J. (2001). Leading with NLP: Essential Leadership Skills for Influencing and Managing People. London, UK: HarperCollins Publishers

O'Connor, J., \& McDermott, I. (2013). Principles of NLP: What it is and How it Works. London, UK: Singing Dragon Jessica Kingsley Publishers.

O'Connor, J., \& Seymour, J. (1993). Neuro-Linguistic Programming: Psychological Skills for Understanding and Influencing People. San Francisco, USA: The Aquarian Press an Imprint of Harper Collins Publishers.

Qiu, W. (2014). Aristotle's Definition of Language. International Journal of English Literature and Culture, Vol. 2, No. 8, pp. 194-202.

Ready, R., \& Burton, K. (2010). Neuro-linguistic Programming for Dummies. $2^{\text {nd }}$ Edition. West Sussex, UK: John Wiley \& Sons, Ltd. 
Reynolds, D. W. (2001). Language in the Balance: Lexical Repetition as a Function of Topic, Cultural Background, and Writing Development. Language Learning, Vol. 51, No. 3, pp. 437-476.

Rieschild, V. R. (2006). Emphatic repetition in spoken Arabic. In Mushin, I. (Ed.) Proceedings of the 2004 Conference of the Australian Linguistic Society (pp. 123). Sydney: Macquarie University Research Grant.

Saad Eldeen, H. (2013, July 1). The Armed Forces Control Maspero. Available, on December 15, 2017, from https://www.elwatannews.com/news/details/214886

Tosey, P., \& Mathison, J. (2009). Neurolinguistic Programming: A Critical appreciation for Managers and Developers. London, UK: Palgrave Macmillan.

Triadafilopoulos, T. (1999). Politics, Speech, and the Art of Persuasion: Toward an Aristotelian Conception of the Public Sphere. The Journal of Politics, Vol. 61, No. 3, pp. 741-757.

Vaden, K. I., Muftuler, L. T., \& Hickok, G. (2010). Phonological RepetitionSuppression in Bilateral Superior Temporal Sulci. Neuroimage, Vol. 49, No.1, pp.1018-1023.

Vaknin, S. (2011). The BIG Book of NLP Techniques: 200+ Patterns, Methods \& Strategies of Neuro Linguistic Programming. 4th Edition. Australia: Inner Patch Publishing.

Vickers, A., \& Bavister, S. (2010). Essential NLP: An Introduction to Neurolinguistic Programming. London, UK: Hodder \& Stoughton General Division.

Webber, B., Stone, M., Joshi, A., \& Knott, A. (1994). Anaphora and Discourse Structure. Computational Linguistics, Vol. 16, No. 1, pp. 1-45.

Wełyczko, L. (2016). Neurolinguistic Programming in the Process of SelfManagement. Journal of Science of the Military Academy of Land Forces, Volume 48 Number 2, pp.139-158.

Wilimzig, C., \& Nielsen, K. (2017). NLP and Psychological Research: Rapport, Reframing and Eye Accessing Cues. Journal of Experiential Psychotherapy, Vol. 20, No. 3, Issue79, pp. 25-36.

Woodhead, E. H. (2010). Anchor Management: A Road-Map for Innovative Problem Solving. New York, USA: iUniverse, INC.

Zaraket, F. \& Makhlouta, J. (2012). Arabic Morphological Analyzer with Agglutinative Affix Morphemes and Fusional Concatenation Rules. Proceedings of COLING 2012, pp. 517-526, Mumbai, India.

Zhang, X. (2005). English Rhetoric. Bejing, China: University of Tsinghua press.

Zulkifli, N. N. (2015). Neurolinguistic Programming (NLP) and Transformational Leadership: A Conceptual Model for Malaysian Women Leader and Representative. Journal of Media and Information Warfare, Vol. 7, pp. 105160. 